Magdalena Machała

Uniwersytet Jagielloński

magda.machala31@gmail.com

\title{
Austromodernizm. Rozszczelnianie paradygmatu
}

\author{
(Marjorie Perloff, Ostrze ironii. Modernizm w cieniu monarchii \\ habsburskiej, tłum. M. Płaza, Wydawnictwo Ossolineum, Wrocław \\ 2018, ss. 344)
}

Austromodernism. Unsealing the Paradigm

„Kiedy piszę książkę, zajmuję się tylko autorami, którzy mnie ciekawią”. W taki sposób Marjorie Perloff w rozmowie z Adamem Lipszycem skomentowała wybór pisarzy, których twórczość interpretuje w swojej najnowszej książce Ostrze ironii. Modernizm w cieniu monarchii habsburskiej. Wybór dla czytelników Perloff tym razem wcale nieoczywisty, ponieważ w swoich poprzednich pracach badaczka skupiała się przede wszystkim na zagadnieniach związanych z poezją amerykańską oraz zachodnioeuropejską literaturą awangardową. Z wyjątkiem książki dotyczącej Ludwiga Wittgensteina² autorka nie poświęcała wiele uwagi kulturze i literaturze austriackiej.

Nazywana „cesarzową krytyki amerykańskiej” Perloff w przedmowie do Ostrza ironii... tym razem przedstawia siebie przede wszystkim jako byłą mieszkankę Republiki Austriackiej, którą opuściła wraz z rodziną w roku 1938, mając wówczas niecałe siedem lat. Historia monarchii habsburskiej i jej rozpadu, zarysowana we wstępie książki i uzupełniana aż do ostatniego rozdziału, stanowi z jednej strony część wspomnień samej Perloff, która jako dziecko słuchała wyidealizowanych opowieści o dawnych monarchach, z drugiej jest dla

1 Czy możemy wreszcie porozmawiać o Wittgensteinie? Rozmowa z Marjorie Perloff, wywiad przeprowadził A. Lipszyc, „Dwutygodnik”, https://www.dwutygodnik.com/artykul/8149-czy-mozemy-wreszcie-porozmawiac-o-wittgensteinie.html, dostęp: 14.03.2019.

2 Zob. M. Perloff, Wittgenstein's Ladder. Poetic Language and the Strangeness of the Ordinary, Chicago 1996. 
badaczki punktem wyjścia do refleksji nad formacją pisarzy, dla których zetknięcie się z kulturą Austro-Węgier było doświadczeniem fundującym. Formację tę Perloff określa operacyjnym terminem austromodernizm i zalicza do niej takich twórców, jak Karl Kraus, Joseph Roth, Robert Musil, Elias Canetti, Paul Celan oraz Ludwig Wittgenstein. Właśnie tym twórcom poświęcone są kolejne rozdziały książki.

Wymienienie jednym tchem tego długiego szeregu nazwisk pisarzy początkowo budzi opór i wydaje się praktyką nieoczywistą. Urodzili się w - oddalonych od siebie niekiedy o setki kilometrów - miastach, które po rozpadzie monarchii wcielone zostały do nowo powstałych państw; narodziny najstarszego z wymienionych (Karl Kraus) i najmłodszego (Paul Celan) dzieli niemal pięćdziesiąt lat różnicy. Są wśród nich poeci, dziennikarze, powieściopisarze, eseiści, publicyści, dramatopisarze oraz filozof. Perloff nie zamazuje tych różnic, nie tworzy szczelnie zamkniętych szufladek opatrzonych etykietką , ,austromoderniści”, gdzie każdy z przywoływanych przez badaczkę twórców znalazłby swoje miejsce, przeciwnie - autorka podkreśla, że jej propozycja nie jest spójną, obszerną monografią dotyczącą pewnego zjawiska literacko-kulturowego.

Czym zatem jest Ostrze ironii...? Można by nazwać tę książkę teoretyczną interwencjąa, która stanowi próbę wypełnienia znaczącej luki w badaniach nad literaturą modernizmu. Według Perloff „w świecie anglojęzycznym austromodernizm niestety wciąż pozostaje białą plamą na kartach historii literatury" (s. 9). Z uniwersyteckich doświadczeń autorki wynika, że Canetti znany jest przede wszystkim jako noblista, Musil jako autor sławnej powieści, której nikt nigdy jednak do końca nie przeczytał, Celan pozostaje wyłącznie „poetą Zagłady", a z kolei Kraus i Roth to pisarze niemal zupełnie zapomniani. I choćjak zauważa Lipszyc - sytuacja w polskim literaturoznawstwie wygląda nieco inaczej i wszystkie interesujące Perloff utwory, z wyjątkiem Ostatnich dni ludzkości Karla Krausa, są u nas znane i czytane ${ }^{4}$, trudno jednak na naszym gruncie o tak wielokierunkowe i jednocześnie porządkujące ujęcie zjawiska austromodernizmu, jak to zaproponowane przez Perloff.

\section{„W cieniu monarchii”}

Polityczna i kulturowa wyjątkowość Austrii - kraju, którego nie można pojmować w kategoriach przestrzennych, bo jego granice w istocie nie mają charakteru geograficznego - wciąż jest o wiele za słabo rozumiana. Tacy poeci i pisarze jak

3 M. Perloff, Ostrze ironii. Modernizm w cieniu monarchii habsburskiej, tłum. M. Płaza, Wrocław 2018. Wszystkie cytaty pochodzą z tego wydania. Przywołując fragmenty, podaję numer strony w nawiasie.

4 Zob. A. Lipszyc, Apokaliptyczna precyzja, czyli „Austria irret in orbe ultima”, posłowie [w:] M. Perloff, Ostrze ironii..., dz. cyt., s. 322. 
Grillparzer czy Hofmannsthal, jak Rilke i Robert Musil nie mogliby być Niemcami. Austriacy byli zanurzeni w wielu różnych kulturach i rozwinęli inną koncepcję świata niż Niemcy (s. 236).

Wypowiedź eseistki i poetki Ingeborg Bachmann dobrze ilustruje, w jaki sposób fenomen kultury austriackiej rozumie sama Perloff. Po pierwsze, autorka Ostrza ironii... również bardzo mocno eksponuje odmienność austromodernizmu od modernizmu niemieckiego rozwijającego się w Republice Weimarskiej. Po drugie, dla niej również granice Austrii tuż po rozpadzie monarchii nie mogą być ujmowane w kategoriach przestrzennych. Perloff, korzystając z fotografii miast i wspomnień ich mieszkańców, a także analiz socjologicznych, ukazuje, w jaki sposób miasta wcielone do państw Europy Środkowej nadal pozostawały pod silnym wpływem kultury promieniującej z zajmującego pozycję centrum Wiednia.

Wpływ tej kultury to jeden z najważniejszych elementów spajających twórczość austromodernistów. Zróżnicowanie i wewnętrzne napięcia, które Perloff zauważa, interpretując poszczególne utwory, wynikają z kolei z drugiego wspólnego doświadczenia tych twórców, czyli z dorastania na prowincji. Badaczka podkreśla, że żaden z interesujących ją autorów, z wyjątkiem Wittgensteina, nie urodził się w Wiedniu. Każdy z nich wychował się w jednym z prowincjonalnych miast monarchii czy, jak w przypadku Celana, w mieście, które mimo wcielenia do Ukrainy pozostawało pod silnym wpływem kultury Austro-Węgier. Pisząc o erotykach Celana czy autobiografii Canettiego, Perloff pokazuje, jak wielki wpływ zarówno na tematykę, jak i język tych tekstów miało dzieciństwo spędzone wśród wieloetnicznych, wielowyznaniowych i wielokulturowych społeczności, których członkowie posługiwali się najczęściej specyficznymi dialektami wielu różnych języków, takich jak niemiecki, bułgarski, polski, czeski, ukraiński, ladino i oczywiście jidysz.

Bohaterów swoich szkiców Perloff nazywa „Żydami prowincjuszami”, stwierdzając jednocześnie, że żyli oni w „jednym z najbardziej antysemickich okresów w nowożytnych dziejach Europy” (s. 11). Zainteresowanie antysemityzmem, które w jednych utworach przyjmowało postać jego przenikliwej analizy, w innych pojawiało się w formie nieuświadamianych, bezrefleksyjnie powtarzanych stereotypów, stanowi kolejną ważną cechę literatury austromodernizmu - przez badaczkę nazywanego „zjawiskiem w dużej mierze austriacko-żydowskim” (s. 11). Jak zauważa, zarówno nasilające się wówczas nastroje antysemickie, jak i naznaczone traumą doświadczenie Wielkiej Wojny, która zakończyła się nagłym rozpadem monarchii, nadało „kiełkującemu modernizmowi głęboko sceptyczny i rozmyślnie indywidualistyczny charakter” (s. 21). To z tego doświadczenia Perloff wyprowadza najważniejszy rys literatury austromodernizmu, czyli jej ironiczność. „Tendencja do podważania wartości normatywnych, zamiłowanie do paradoksu i sprzeczności jako narzędzi 
interpretacyjnych, zwłaszcza zaś ostra jak brzytwa, groteskowo komiczna ironia” (s. 26) charakteryzują wszystkie interpretowane przez nią utwory.

\section{Ironia literacka jako „domena różnorodności””}

W obszernym wstępie do książki autorka nie wprowadza żadnej pełnej definicji ironii, nie odwołuje się także do dobrze znanych klasycznych podziałów, jak choćby tego rozróżniającego między ironią sokratyczną, retoryczną i romantyczną. Dopiero uważna lektura i wnikliwa interpretacja kolejnych utworów pozwalają Perloff na jej dookreślanie, ukazanie tego, w jaki sposób działa ona w konkretnym tekście. W szkicu $O$ ironii jako kategorii literackiej Beda Allemann pisał:

Sygnały ironii literackiej należą do gatunku tak dobrze ukrytych, że niemal nie mamy już prawa mówić o sygnałach. (...) Ironia literacka jest tym bardziej ironiczna, im bardziej zdecydowanie potrafi zrezygnować z ironicznych sygnałów, nie tracąc swej przejrzystości. (...) To, co jest ironiczne w tekście, uwidacznia się stale dopiero w związku z kontekstem [podkr. - M.M.] ${ }^{6}$.

W Ostrzu ironii... Perloff ukazuje się właśnie jako wyczulona na te najbardziej subtelne sygnały interpretatorka, która w odpowiednim miejscu przywołuje najrozmaitsze konteksty, począwszy od biograficznych do socjologiczno-politycznych i wreszcie filozoficznych. I tak na przykład w szkicu o Marszu Radetzky'ego Josepha Rotha analiza struktur społecznych charakterystycznych dla prowincjonalnych miast monarchii w pierwszej i drugiej dekadzie XX wieku staje się niezbędnym kontekstem do odczytania obecnej w tej powieści ironii. Autorka wskazuje na rozwijającą się w rozmowach i działaniach bohaterów sieć napięć dotyczących ich własnej pozycji społecznej. Ci, którzy zdobyli ją dzięki niespodziewanej nobilitacji, bronią teraz stabilności hierarchii, uniemożliwiając awans innym. „Ironia polega na tym, że podziały klasowe, chociaż tak ewidentne, już wcześniej zdążyły ulec erozji” (s. 96).

Na przykładzie „miażdżącego” antywojennego dramatu Ostatnie dni ludzkości Karla Krausa, który składa się przede wszystkim:

z autentycznych dokumentów: gazetowych depesz, artykułów redakcyjnych, publicznych obwieszczeń, protokołów z zebrań politycznych, manifestów, listów,

M. Głowiński, Ironia jako akt komunikacyjny [w:] Ironia, red. tenże, Gdańsk 2002, s. 8.

6 B. Allemann, O ironii jako kategorii literackiej, tłum. M. Darmińska-Joczowa [w:] Ironia, dz. cyt., s. 26-27. 
pocztówek, wywiadów - dosłownie wszystkiego, co składało się na pisemną dokumentację lat Wielkiej Wojny (s. 52),

Perloff eksponuje z kolei ten rodzaj ironii, który demaskuje absurdalność świata tuż przed wojną i w jej trakcie. O intensyfikację doświadczenia absurdu oraz za jego reprodukowanie zarówno Kraus, jak i sama autorka obwiniają przede wszystkim media. Jak pisze Perloff, w diagnozowaniu ich roli „podczas pierwszej wojny światowej - ale też w antycypowaniu ich wpływu na przebieg późniejszych wojen - satyryczny dramat Krausa nie ma sobie równych" (s. 84). Badaczka przedstawia słabo znanego w Polsce pisarza i dziennikarza jako autora niezwykle aktualnych i przenikliwych tez dotyczących dyskursu medialnego, które dziś kojarzą się przede wszystkim z opisaną przez Judith Butler w Ramach wojny kategorią czy też praktyką ramowania rzeczywistości'. Według Krausa i Butler media, stwarzając własne ramy i narzucając je społeczeństwu, stają się aktywnymi uczestnikami działań wojennych.

W twórczości wszystkich sześciu pisarzy Perloff zainteresowana jest szczególnie tym rodzajem ironii, który - według jednego z największych ironistów, Musila - „z góry tkwi w stosunkach zachodzących między rzeczami”, jest „stanem świata"

Wraz z szerokim filozoficzno-egzystencjalnym sposobem rozumienia ironii rzeczy, badaczka przejęła od autora Cztowieka bez wtaściwości także postawę eseistki. W jednym z najsłynniejszych fragmentów powieści narrator stwierdza, że esej „oświetla przedmiot z wielu stron, nie ogarniając go całkowicie (...), nie zawiera kompletnego rozwiązania, a jedynie serię rozwiązań poszczególnych" (s. 148-150). W tym sensie książkę Perloff można nazwać zbiorem esejów, które z różnych perspektyw próbują opowiedzieć o pewnej formacji pisarzy.

$\mathrm{Z}$ jednej strony propozycja badaczki stanowi próbę systematyzacji bardzo rozległego obszaru literatury, a - w przypadku Wittgensteina - również filozofii, jest gestem wskazania na austromodernizm jako na całość, która posiada cechy wspólne. $\mathrm{Z}$ drugiej strony autorka nieustannie problematyzuje ten podział, pokazuje, na czym polegał wpływ kultury Austro-Węgier na konkretnych pisarzy, za każdym razem cieniując, wskazując na jego odmienne aspekty. Wojna, antysemityzm, sceptycyzm i ironia stają się wspólnymi tematami, jednym motywem, który w każdym z rozdziałów zyskuje inne znaczenie.

Przyjęta przez badaczkę strategia pisania do czytelnika ,spoza obszaru kultury niemieckiej" (s. 10) oraz próba wprowadzenia do historii literatury nowego terminu sprawiają oczywiście, że niekiedy Perloff rezygnuje z postawy eseistki na rzecz stworzenia maksymalnie jasnego przekazu, dlatego też Ostrze ironii... nie jest pracą pozbawioną uproszczeń czy wręcz błędnych założeń,

7 Por. J. Butler, Ramy wojny. Kiedy życie godne jest optakiwania?, tłum. A. Czarnacka, Warszawa 2011.

8 Por. O ironii Musilowskiej: B. Allemann, dz. cyt., s. 32-40. 
a do takich należy utożsamienie modernizmu z literaturą awangardową. Służy ono autorce do przeciwstawienia literatury eksperymentu formalnego (Wirginia Woolf, James Joyce, poezja awangardowa) literaturze austromodernizmu, której ironiczny charakter oraz „zamiłowanie do paradoksu” miałyby się stać „trwalszym dziedzictwem epoki niż awangardowe innowacje formalne” (s. 26). Autorka - intencjonalnie czy też nie - sprowadza znaczenie i zasługi największych dzieł angielskiego czy francuskiego modernizmu do wprowadzenia strategii punktu widzenia czy symultaniczności narracji. Zapomina tym samym, że ironia, którą tak cenili austromoderniści, była - jak pisze Ryszard Nycz „kluczową postawą artystyczno-światopoglądową" przyjmowaną przez wielu pisarzy nowoczesnych.

Tego typu postawę - bardziej ekskluzywną niż inkluzywną - można także wytłumaczyć perspektywą, z jakiej Perloff pisała tę książę. W Ostrzu ironii... badaczka wielokrotnie podkreśla, że interesujący ją twórcy to pisarze najczęściej niedoczytani, marginalizowani. Podkreśleniem ich odrębności, ukazaniem ich jako osobnej formacji Perloff wypełnia ową lukę w badaniach nad modernizmem, o której pisała w przedmowie. Jej praca jest ożywczą próbą rozszczelnienia modernistycznego paradygmatu, na który w istocie składają się przede wszystkim dzieła literatury niemieckiej, angielskiej i francuskiej, pozostając jednocześnie przede wszystkim zapisem prywatnej lektury bliskich autorce utworów.

9 R. Nycz, Język modernizmu. Prolegomena historycznoliterackie, Wrocław 2002, s. 106. 